\title{
Vibration Based Piezoelectric Energy Harvesting Utilizing Bridgeless Rectifier Circuit
}

\author{
(Penuaian Tenaga Berdasarkan Getaran Piezoelektrik Menggunakan \\ Litar Penerus Bridgeless)
}

Mahidur R. Sarker*, Azah Mohamed \& Ramizi Mohamed

\begin{abstract}
The energy harvesting technique has the capability to build autonomous, self-powered electronic systems that does not depend on the battery power for driving the low power electronics devices. In this paper, a voltage doubler and bridgeless boost rectifier power electronic converter is proposed to increase the energy harvesting output voltage from piezoelectric vibration based transducer. The conventional full-wave diode bridge rectifier and boost converter for energy harvesting system increases significant voltage drop and power losses in the circuit. However, the proposed voltage doubler and bridgeless boost rectifier circuit reduce the voltage drop and power loses in the circuit and thus increases the efficiency of the circuit. The proposed voltage doubler and bridgeless boost rectifier circuit step-up the output voltage up to 3 V DC from an input voltage of $1.9 \mathrm{VAC}$.
\end{abstract}

Keywords: Energy harvesting; rectifier-less converter; low-voltage; piezoelectric; voltage doubler

\section{ABSTRAK}

Teknologi penuaian tenaga mempunyai keupayaan untuk membina autonomi, sistem elektronik yang berkuasa sendiri yang tidak bergantung kepada kuasa bateri untuk operasi mereka. Dalam kertas ini, suatu pendua voltan dan bridgeless rangsangan penerus kuasa penukar elektronik adalah dicadangkan untuk cekap menguruskan tenaga dituai dari transduser piezoelektrik getaran dengan input voltan rendah. Konvensional penuh gelombang diod penerus jambatan untuk sistem penuaian tenaga kehilangan kejatuhan voltan yang ketara dan juga meningkatkan kehilangan kuasa litar dan kesukaran. Konvensional penuh gelombang cahaya jambatan ac-dc penerus dengan litar Boost penerus dan cadangan rangsangan bridgeless penerus untuk sistem tenaga penuai kedua-duanya telah disimulasikan menggunakan MATLAB / SIMULINK. Litar maju yang terdiri daripada transduser piezoelektrik getaran dengan sumber input, voltan litar pendua, bridgeless litar penerus rangsangan dengan peranti storan. Input AC voltan $1.9 \mathrm{~V}$ dengan amplitud diperbetulkan dan melangkah sehingga $3 \mathrm{VDC}$.

Kata Kunci: Penuaian tenaga; penerus-kurang penukar; voltan rendah; piezoelektrik; pendua voltan

\section{INTRODUCTION}

The energy harvesting from the ambient energy sources, such as solar, wind, thermal, sound, vibration, solid waste etc, is commonly popular now-a-days due to rising power demand. The demand of power harvesting is increasing using piezoelectric material as mechanisms to transfer mechanical energy into electrical energy. Generally, ambient vibration that converts into electrical energy can be stored and used to power other devices, now greater concern to be researched. The need of power conversion circuits for energy harvesting applications has increased (Chao et al. 2001). Previously few researchers have been conducted regarding the energy harvesting from the vibrations (Muralta et al. 2009). Vibration energy refers to the energy harvested from mechanical motion. Usually a converter is required to transform mechanical movement into electricity which then powers electronic systems. The piezoelectric effect and other methods to extract power from vibration includes the electrostatic effect (capacitive) or electromagnetic effect (inductive) of vibration energy conversion. Vibration energy conversion can be powered from sources such as the human body or powered from machinery. Some materials (e.g. ceramics and crystals), have the ability to build up the potential in response to mechanical pressure. One good example of harvesting energy from mechanical movement is from industry, where vibration energy converters harvest energy and power wristwatches. Researcher in (Stark 2006) analysed regular vibration sources such as cars, buildings and trains which can be employed by sensor nodes. 
Among the various modes of energy harvesting, vibration energy harvesting is the most versatile technique developed in the literature (Hua et al. 2014). Three main mechanisms of vibration-to-electrical energy conversion exist including electrostatic, electromagnetic, and piezoelectric transducer. Review articles highlighting work performed on all of the transducer mechanisms (Beeby 2006). Among the three modes of vibration harvesting, piezoelectric energy harvesting has received the most attention, with three review articles dedicated to recent research on piezoelectric transducer (Anton \& Sodano 2007; Brian \& Sang-Gook 2005; Roundy 2005).

Piezoelectric vibration harvesting is attractive mainly due to the simplicity of piezoelectric transducer and the relative ease of implementation of piezoelectric systems in a wide variety of applications as compared to electrostatic or electromagnetic methods (Emmanuel 2011). The transducer is the key component of the energy harvesting technology. Figure 1 shows the general block diagram of the energy harvesting systems. Piezoelectric energy harvesting can benefit from a multifunctional approach by combining several functions into a single device, such as energy harvesting, energy storage, and structural load bearing ability, that when combined with a host structure can provide a more effective whole system. The introduction of multi-functionality into energy harvesting systems grips potential to raise their value and functionality, and stimulate the amalgamation of harvesting systems into many engineering applications. Table 1 summarizes the advantages and disadvantages for the above mentioned piezoelectric vibration energy harvesting technologies (Taware1 et al. 2010). The benefits of power harvesting devices are that they reduce or eliminate the dependency electronic circuit into piezoelectric generator will be maintenance-free in comparison with the use of battery that commonly requires a periodic replacement while extending the lifetime of devices (Meiling \& Emma 2009; Guan \& Liao 2008).

The behaviors are piezo material; if any kinds of force or stress apply it will produce alternating current (AC). In this case, to run electrical applications (i.e., micro-devices), AC from piezoelectric energy harvesting (PEH) needed to be transformed into direct current (DC) by a rectifier. Generally, full bridge rectifier circuit (FBRC) and boost converter is commonly used in PEH circuits (Ottman 2002; Ottman 2003). Hence, forward voltage of the diode in the rectifiers has non-negligible power loss in low voltage circuits. So, a half-wave voltage doubler (VD) and boost converter circuit is proposed with piezoelectric vibration transducer. After that, it has been compared with the FBRC and boost converter circuit. The advantages using of the VD circuit compare to FBRC the number of diodes are half from the bridge rectifier and VD circuit can maximize power the output of the piezoelectric vibration transducer, which is twice that of the FBRC. As a result, the maximum output power of the PEH circuit using a half-wave VD rectifier is higher than that of the FBEH circuit.

The ultimate goal of this study is to design a low voltage bridgeless energy harvesting circuit utilizing vibration piezoelectric transducer. The developed energy harvesting circuit consumes very little power, and is especially suitable for the micro-devices, where ambient harvested power is very low. Finally, the complete conventional and proposed energy harvesting circuits have been developed and simulated using the Matlab software. The rest of the paper is organized as follows: Section 2 represents methodology; Section 3 describes conventional energy harvesting circuit. Section 4 denotes proposed energy harvesting circuit. Section 5 represents experimental setup. Section 6 represents simulation results and finally, conclusion is given in section 7 .

TABLE 1. Advantages and disadvantages of piezoelectric vibration energy harvesting (Taware1 \& Deshmukh 2010)

\begin{tabular}{lllc}
\hline Mechanism & \multicolumn{1}{c}{ Advantages } & \multicolumn{1}{c}{ Disadvantages } & Challenges \\
\hline & No voltage source required & -Regular and constant inspections & \\
& Higher output voltage & for moderate the effects of the & \\
-Exploitation of waste mechanical & $\begin{array}{l}\text { heavy traffic loads } \\
\text {-Not appropriate for large scale } \\
\text { energy }\end{array}$ & $\begin{array}{c}\text { Decreased coupling } \\
\text { of thin-films }\end{array}$ \\
Vibration & -Cooperation with side-smaller cars & energy harving & \\
piezoelectric & $\begin{array}{l}\text { applications } \\
\text { (batteries, powering traffic lights, }\end{array}$ & & \\
& sings) & & \\
& -New hybrid vehicle-technology & & \\
& can be enhanced & & \\
& by its applicability & & \\
\hline
\end{tabular}




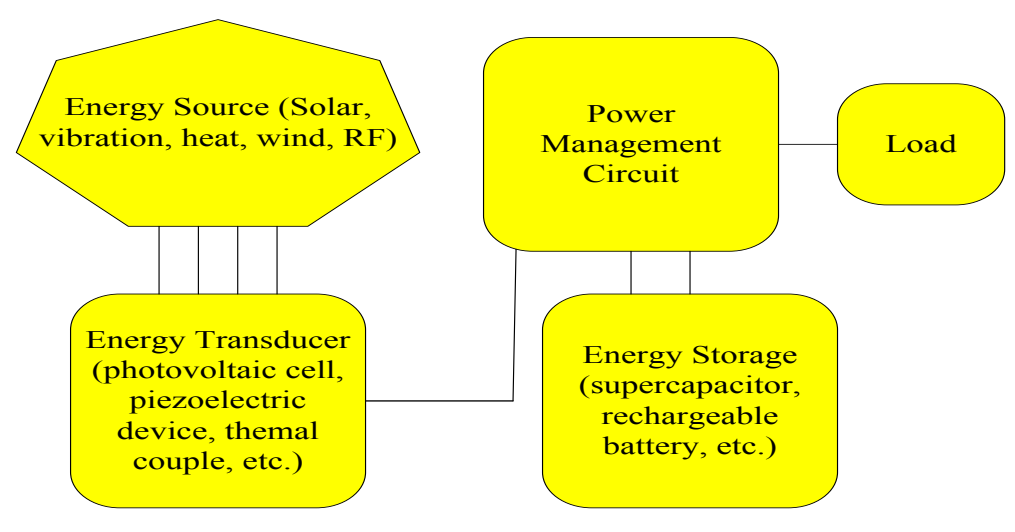

FIGURE 1. General block diagram of energy harvesting system

METHODOLOGY

The conventional circuit is not suitable to design the low voltage energy harvesting circuits (EHC) because lacking of low voltage supply. The components such as Schottky diode and MOSFET (IRF7853) are chosen to design the proposed EHC. The piezoelectric vibration transducer (PVT) was constructed by commercially model EH220-A4-503YB. The input voltage (Vrms $1.9 \mathrm{~V})$ is selected that produce PVT. The output voltage of PVT Vrms $1.9 \mathrm{~V}$ is used as input voltage of conventional and proposed EHC. The proposed EHC is simulated using Matlab software to design a suitable circuit. The simulation results of the conventional and the proposed EHC are verified and compared. The flow chart of this study is performed using the following design-flow as shown in Figure 2.

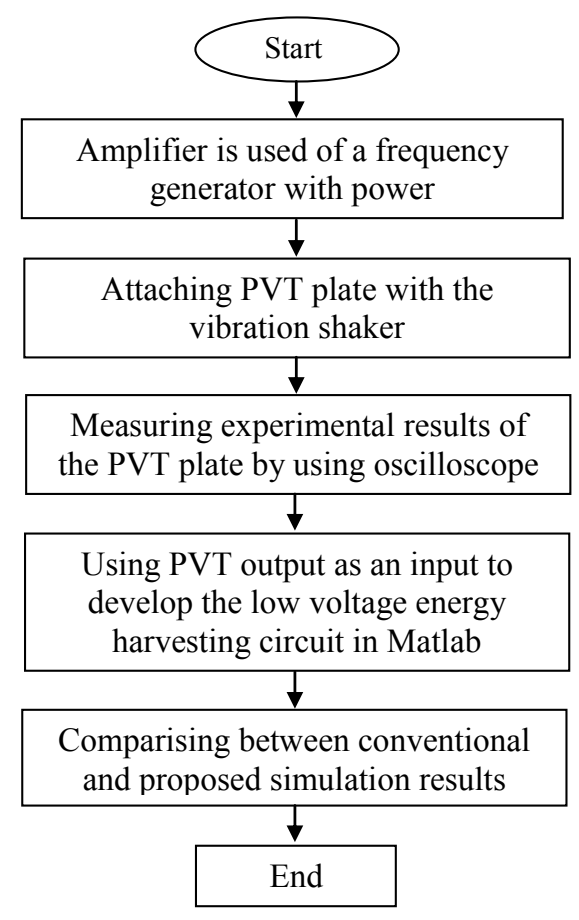

FIGURE 2. Flow chart of the proposed design
CONVENTIONAL ENERGY HARVESTING CIRCUIT

The power electronic circuit plays an important role between piezoelectric transducer and electronic load, which might include a battery (Szarka et al. 2012) in energy harvesting system. The power electronic circuits are applied to rectified, step-up and regulate the power delivered to the load, and actively manage the electrical damping of the transducers so that maximum power could be transferred to the load (Cammarano 2010; Cheng 2007). The output voltage level of the micro scale harvesting devices is usually in the order of a few hundred millivolts depending on the topology of device (Dayal \& Parsa 2010; Mitcheson 2010). The output AC voltage should be rectified, boosted, and regulated by power converters to fulfil the voltage requirement of the loads. The conventional energy harvesting circuits consisting of piezoelectric element, AC-DC rectifier and boost converter are shown in Figure 3. Many vibration-based energy harvesting systems use a piezoelectric transducer as an AC source (Ottman et al. 2002), Priya, S. 2007; Lefeuvre et al. 2007).

It generates $\mathrm{AC}$ voltage which must first be rectified before it can be used in load. Typically, the energy from a piezoelectric transducer that has two electrodes is rectified using a full-wave diode bridge rectifier, which requires a significant voltage drop between input and output, decreasing the rectifier voltage efficiency. The extract piezoelectric strain energy will produce an AC voltage as an electrical energy. However, most of the low power electronic device nowadays only uses a low DC voltage. Therefore, the AC output voltage needs convert to the usable DC voltage to supply in the load. The boost converter is stepup and regulates DC voltage to drive low power electronic devices. The boost converter contains switch $M 1$, diode $D 5$, inductor $L 1$, and capacitor $C 1$. The control and gate drive of this circuit is also very simple, only switch $M 1$ needs to be controlled and gate drive shares the same ground with the input voltage source. A conventional interface circuit is not fully efficient to convert AC to DC signal and to increase the voltage in electrical applications because the forward voltage of diode potential is higher than the input source (Lefeuvre et al. 2007; Yuan \& David 2011) 


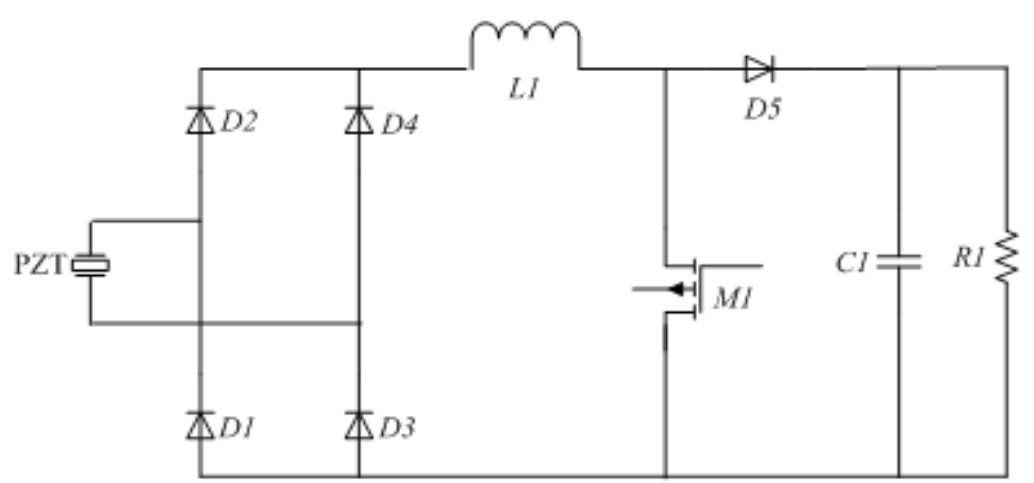

FIGURE 3. Conventional rectifier with boost converter

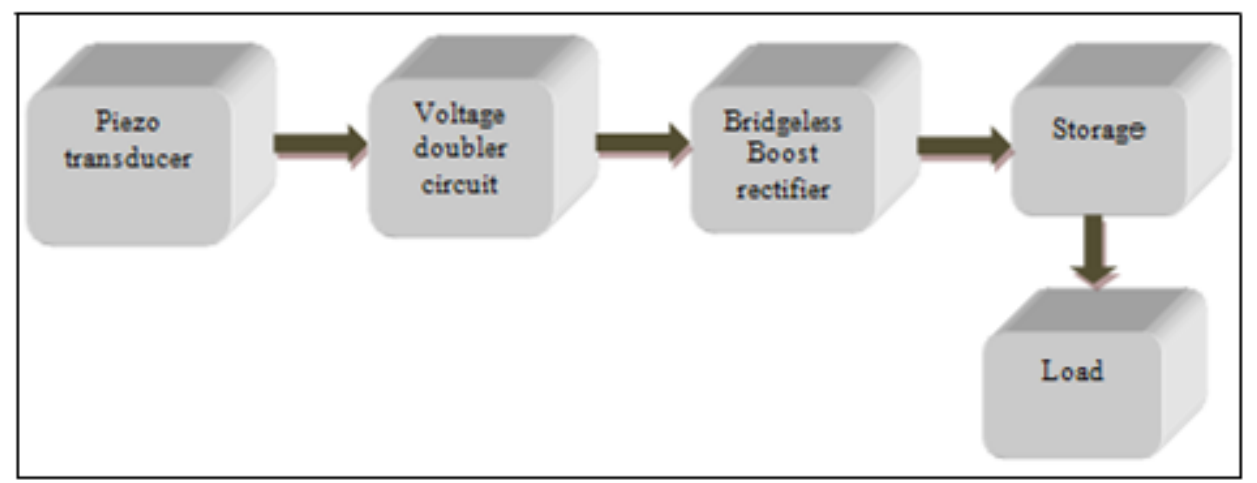

FIGURE 4. Block diagram of the proposed energy harvesting circuit

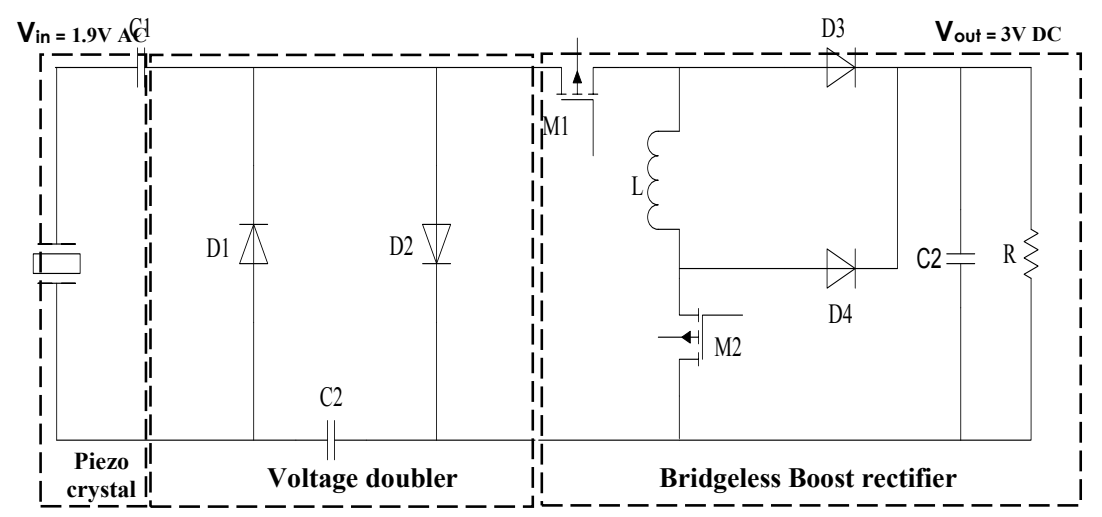

FIGURE 5. Circuit diagram of the developed energy harvester system with the PVT, voltage doubler and bridgeless boost rectifier using storage device etc

\section{PROPOSED ENERGY HARVESTING CIRCUIT}

This section provides the proposed block diagram of fully energy harvesting circuit with piezoelectric transducers, voltage doubler with bridgeless boost rectifier and a temporary storage device as shown in Figure 4.

In the general power harvesting system, there is a transducer that harvests energy and then converts it into electrical power. The transducer can be mechanical vibration-based energy harvesting system use piezoelectric transducer as AC power source, whose output voltage need to rectify before supply into load. Usually piezoelectric vibration transducer produced is very low voltage (i.e., 0.3 V 0.7 V) (Yuan \& David 2011).
The fully energy harvester system is developed using voltage doubler (VD) circuit, bridgeless boost rectifier circuit and temporary storage device. A VD circuit is designed for increasing the AC voltage because the output voltage of the piezoelectric vibration transducer is low. Each VD consists of two Schottky diodes and two capacitors. At the initial stage of the VD, the first diode anode is tied to ground. As the PVT input voltage goes to negative, the diode becomes forward biased, allowing charge to flow on the first capacitor. Once the voltage on the first capacitor is high enough, the second diode turns "ON" and begins conducting. This current then flows on the second capacitor, with twitch the voltage as the first (assuming no voltage 


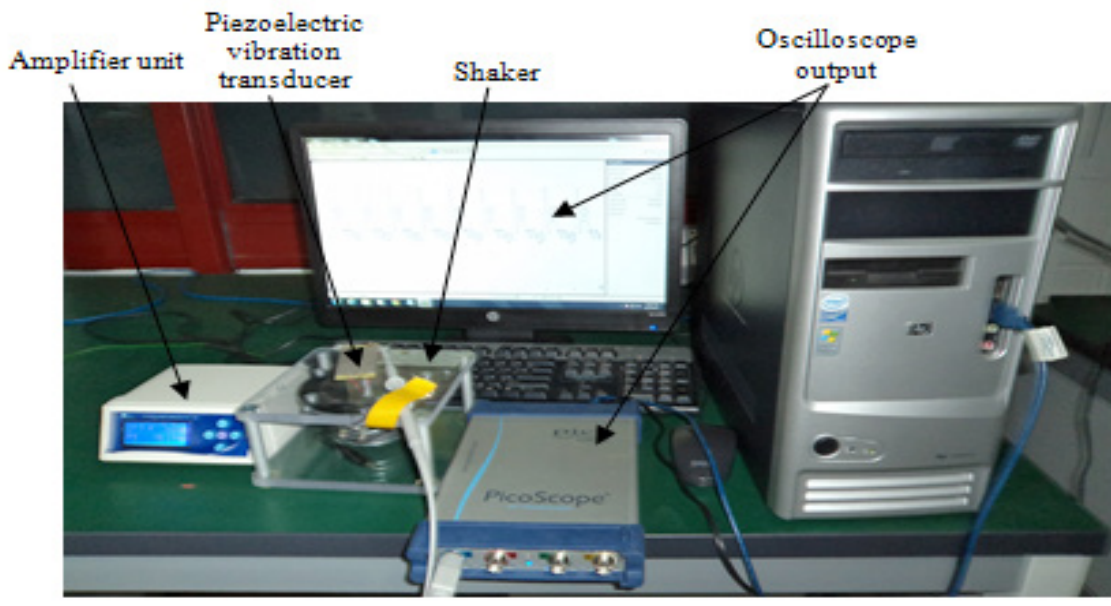

FIGURE 6. Experimental setup of the energy harvester

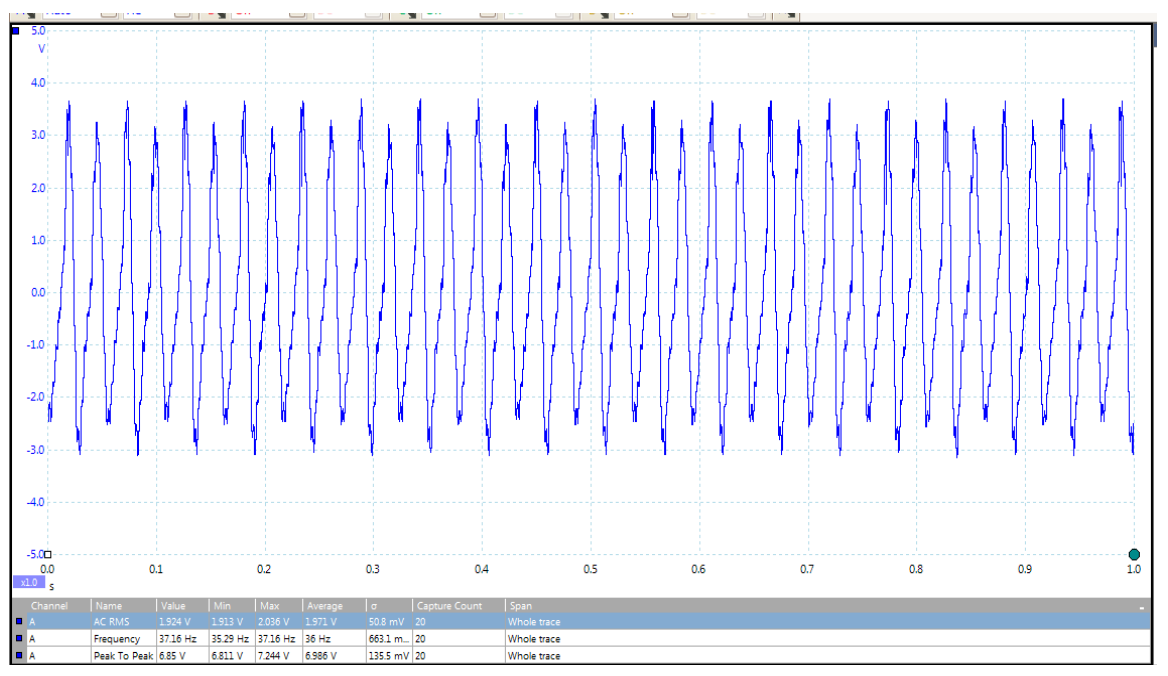

FIGURE 7. Experimental voltage output swing of PVT

drop across the diode). This comprises one VD stage. By cascading additional stages, it is possible to further boost the input voltage. A bridgeless boost rectifier circuit is also developed to stabilize the rectified voltage step-up the desired voltage level. The constant duty of $60 \%$ Pulse signal is used to control MOSFET for boost converter circuit. To storage the step-up voltage, the storage device (i.e., super-capacitor) is used for the purpose of voltage storage. The input current ripple is small; the total cost of the circuit is also relatively low. Because of these good features of proposed circuit, it has more advantage. This stable output voltage $3 \mathrm{~V}$ is capable to run the micro-devices (i.e., biomedical device and WSN etc.). The completed simulated circuit diagram is shown in Figure 5.

\section{EXPERIMENTAL SETUP}

The piezo systems was constructed by a commercial energy harvesting PVT model (EH220-A4-503YB) with mini vibration shaker, amplifier unit and PicoScope 6000 oscilloscope detail layout for the experimental test setup is shown in Figure 6. The energy harvesting bender is a pre-mounted and prewired double quick-mount bending generator. By vibration shaker bending these structures they will produces electrical energy. In order to keep the condition for mechanical energy generation constant, the use of a frequency generator with power amplifier is preferred. The PVT was connected to oscilloscope and linked to the computer. Figure 7 represents the measured input voltage of frequency $37 \mathrm{~Hz}$, Vrms $1.9 \mathrm{~V}$ and Vpp 6.85 V. The Vrms 1.9 V of PVT is applied as an input to develop the conventional and develop energy harvesting circuit described in section 3 and section 4 .

\section{SIMULATION RESULTS}

This section describes the outcome of the improvement results of the energy harvester conventional and proposed circuit results which was simulated and verified. The low voltage energy harvesting conventional and proposed circuits simulation results are compared. 
SIMULATION RESULTS OF THE

CONVENTIONAL CIRCUIT

The simulation results of the conventional energy harvesting circuit are shown in Figure 8(a) and Figure 8(b). Figure 8(a), represent that the output voltage of full bridge rectifier is $0.4 \mathrm{~V}$, corresponding to the input voltage of 1.9 $\mathrm{V}$ and it is stable after every $0.1 \mathrm{~s}$. The maximum output voltage of boost converter is $0.9 \mathrm{~V}$, corresponding to the output voltage of rectifier $0.4 \mathrm{~V}$ as shown in Figure 8(b) and it is stable from $0 \mathrm{~s}$.

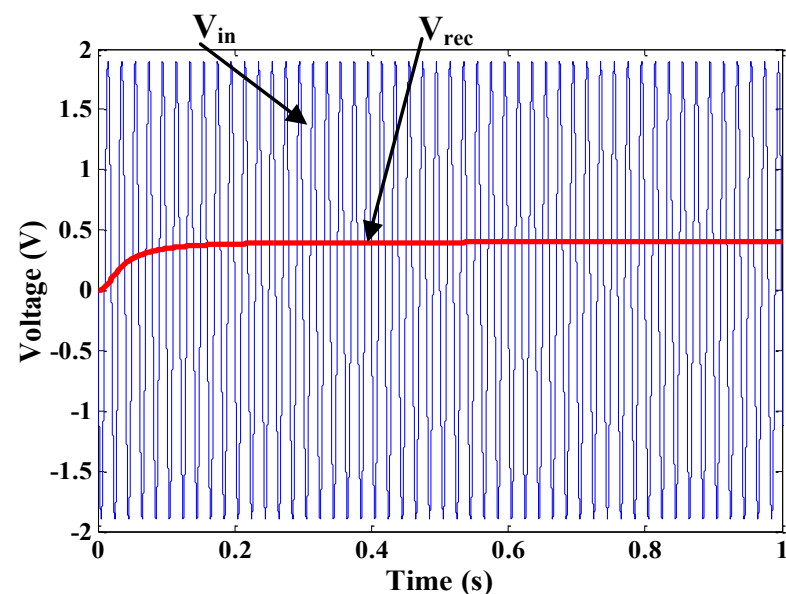

(a)

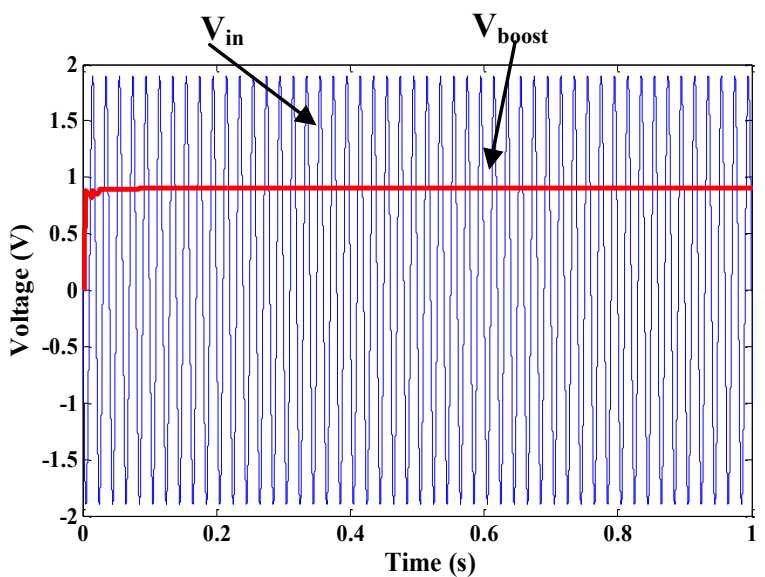

(b)

FIGURE 8. (a) Result of the conventional full wave rectifier, (b) Result of the conventional full wave rectifier with boost converter

\section{SIMULATION RESULTS OF THE PROPOSED CIRCUIT}

The output voltage of proposed EHC is $3 \mathrm{~V}$ DC corresponding to the input Vrms of $1.9 \mathrm{~V}$ as shown in Figure 9. The curve shows the horizontal voltage range between $-2 \mathrm{~V}$ to $3 \mathrm{~V}$. That times range of the voltage is between $0 \mathrm{~s}$ to $1 \mathrm{~s}$. From Figure 9, it can be observed that the curve is becoming bent; initially, it takes some time to reach the voltage; after 0.4 $\mathrm{s}$, it becomes constant. The comparison simulation results between conventional and proposed energy harvesting circuit as shown in Table 2. The Comparison efficiency of conventional and proposed EHC as shown in Table 3.

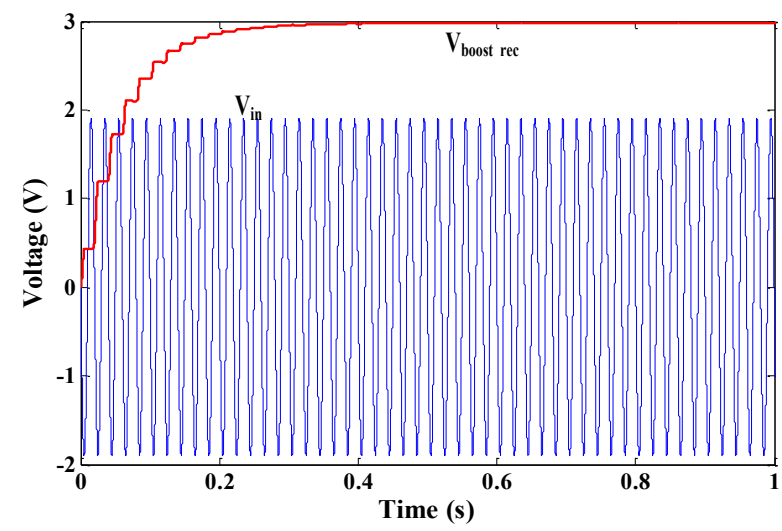

FIGURE 9. Output voltages of PVT and boost rectifier circuit

TABLE 2. Comparison simulation results between conventional and proposed energy harvesting circuit

\begin{tabular}{lccc}
\hline Parameter & Conventional & Proposed & Applications \\
\hline $\begin{array}{l}\text { Input } \\
\text { voltage }\end{array}$ & 1.9 & 1.9 & $\begin{array}{c}\text { Micro-devices } \\
\text { (i.e., WSN, } \\
\text { (V) }\end{array}$ \\
$\begin{array}{l}\text { Output } \\
\text { voltage }\end{array}$ & 0.9 & $3 \mathrm{~V}$ & \\
$\begin{array}{l}\text { (V) } \\
\text { Frequency } \\
(\mathrm{Hz})\end{array}$ & 37 & 37 & \\
\hline
\end{tabular}

The efficiency of the system is calculated as follows for the input power of $126.7 \mathrm{~mW}$

(Voltage $1.9 \mathrm{~V}$ and current $67 \mu \mathrm{A}$ ).

For conventional circuit,

OutputPower $=\frac{(\text { OutputVoltage })^{2}}{\text { Loadresis } \tan c e}=\frac{(0.9 \mathrm{~V})^{2}}{100 \Omega}=8.10 \mathrm{~mW}$

Power Efficiency $=\frac{\text { OutputPower }}{\text { InputPower }} * 100 \%$

$$
\begin{aligned}
& =\frac{8.10 \mathrm{~mW}}{126.7 \mathrm{~mW}} \\
& =6.3 \%
\end{aligned}
$$

For proposed circuit,

$$
\begin{aligned}
& \text { OutputPower }=\frac{(\text { OutputVoltage })^{2}}{\text { Loadresis } \tan c e}=\frac{(3 \mathrm{~V})^{2}}{100 \Omega}=90 \mathrm{~mW} \\
& \text { Power Efficiency }=\frac{\text { OutputPower }}{\text { InputPower }} * 100 \% \\
& =\frac{90 m W}{126.7 m W} \\
& =71 \%
\end{aligned}
$$


TABLE 3. Comparison efficiency of conventional and proposed energy harvesting circuit

\begin{tabular}{cccccc}
\hline Parameter & $\mathrm{P}_{\text {in }}(\mathrm{mW})$ & $\mathrm{R}(\Omega)$ & $\mathrm{V}_{\text {our }}(\mathrm{V})$ & $\mathrm{P}_{\text {out }}(\mathrm{mW})$ & $\eta \%$ \\
\hline $\begin{array}{c}\text { Conventional } \\
\text { Proposed }\end{array}$ & 126 & 100 & $0.9 \mathrm{~V}$ & 8.10 & 6.3 \\
& & 3 & 90 & 71 \\
\hline
\end{tabular}

\section{CONCLUSION}

This paper presented energy harvesting circuit based on voltage doubler and bridgeless boost rectifier circuit to increase output voltage to run the low power electronics device. To evaluate the performance of the proposed energy harvesting circuit, the results of proposed circuit was compared with the results of conventional circuit. The benefits of the proposed circuit are enable to step-up at $3 \mathrm{~V}$ DC voltage using an input Vrms $1.9 \mathrm{~V}$ AC. The output voltage is suitable to drive micro devices application. The overall circuit efficiency is greater than $71 \%$, followed by the simulation results.

\section{ACKNOWLEDGEMENTS}

This work was carried out with the financial support from the Ministry of Higher Education of Malaysia under the research grant DPP-2015-136.

\section{REFERENCES}

Anton, S. R. \& Sodano, H. A. 2007. A review of power harvesting using piezoelectric materials (2003-2006). Smart Materials and Structures 16(3): 1-21.

Beeby, S. P., Tudor, M. J. \& White, N. M. 2006. Energy harvesting vibration sources for microsystems applications. Measurement Science and Technology 17(12): R175-R195.

Brian, L. W., \& Sang-Gook, K. 2005. Design Considerations for MEMS-Scale Piezoelectric Mechanical Vibration Energy Harvesters. Integrated Ferroelectrics 71:121160.

Cammarano, A., Burrow, S. G. \& Barton, A. \& Clare, L. R. 2010. Tuning a resonant energy harvester using a generalized electrical load. Smart Mater Structures 19(5):1-7.

Chao, L., Vijay, R. \& Kaushik, R. 2011. Efficient Design of Micro-Scale Energy Harvesting Systems. IEEE Journal on Emerging And Selected Topics in Circuits and Systems 1(3): 254-266.

Cheng, S., Wang, N. \& Arnold, D. P. 2007. Modeling of magnetic vibrational energy harvesters using equivalent circuit representations. J. Micromech. Microeng 17(11):2328-2335.

Dayal, R. \& Parsa, L. 2010. A new single stage AC-DC converter for low voltage electromagnetic energy harvesting. IEEE Energy Convers. Congr. Expo, Atlanta, GA, USA. 4447-4452.
Emmanuel, B., Andreas, G., Patrick, J. S. \& Korvink, G. 2011. A low-cost electromagnetic generator for vibration energy harvesting. IEEE Sensors Journal 11(1):107-113.

Guan, M. J. \& Liao, W. H. 2008. Characteristics of energy storage devices in piezoelectric energy harvesting systems. Journal of Intelligent Material Systems and Structures 19:671-680.

Hua, Y., Jielin, Z., Licheng, D. \& Zhiyu, W. 2014. A vibration-based MEMS piezoelectric energy harvester and power conditioning circuit. Sensors 14:3323-3341.

Lefeuvre, E., Audigier, D., Richard, C. \& Guyomar, D. 2007. Buck-boost converter for sensor less power optimization of piezoelectric energy harvester. IEEE Trans Power Electron 22(5): 2018-2025.

Meiling, Z. \& Emma, W. 2009. Design and Testing of Piezoelectric Energy Harvesting Devices for Generation of Higher Electric Power for Wireless Sensor Networks. $8^{\text {th }}$ annual IEEE conference on Sensors 25-28 October, Christchurch New Zealand: $1-4$.

Mitcheson, P. D., Green, T. C. \& Yeatman, E. M. 2007.Power processing circuits for electromagnetic, electrostatic and piezoelectric inertial energy scavengers. Microsyst Technol. 13(11):1629-1635.

Muralta, P., Marzenckib, M., Belgacema, B., Calamea, F., Basrourb, S. 2009. vibration energy harvesting with PZT micro device. Procedia Chemistry 1:1191-1194.

Ottman, G. K., Hofmann, H. F. \& Lesieutre, G. A. 2003. Optimized piezoelectric energy harvesting circuit using step-down converter in discontinuous conduction mode. IEEE Trans. Power Electron 18(2):696 - 703.

Ottman, G. K., Hofmann, H. F., Bhatt, A. C. \& Lesieutre, G. A. 2002. Adaptive piezoelectric energy harvesting circuit for wireless remote power supply. IEEE Trans. Power Electron 17(5): 669 -676.

Priya, S. 2007. Advances in energy harvesting using low profile piezoelectric transducers. Journal of Electroceramics 19(1): 167-184.

Roundy, S. J. 2005. On the effectiveness of vibration-based energy harvesting. Journal of Intelligent Material Systems and Structures 16(11): 809-823.

Stark, I. 2006. Thermal energy harvesting with thermo life. Proceeding of International Workshop, In Wearable and Implantable Body Sensor Networks, 19-22.

Szarka, G. D., Stark, B. H. \& Burrow, S. G. 2012. Review of power conditioning for kinetic energy harvesting systems. IEEE Trans. Power Electron 27(2): 803-815. 
Taware1, S. M., Deshmukh, S.P. 2010. A review of energy harvesting from piezoelectric materials. Journal of Mechanical and Civil Engineering: 43-50.

Yuan, R., David, P. A. 2011. Input-powered energy harvesting interface circuits with zero standby power. IEEE Transactions 37(5): 1992-1999.

\section{Mahidur R. Sarker*}

Azah Mohamed

Ramizi Mohamed

Department of Electrical, Electronic and System

Engineering,

Faculty of Engineering and Built Environment,

Universiti Kebangsaan Malaysia,

43600 UKM, Bangi, Malaysia

*Corresponding author; email: mahidur@siswa.ukm.edu.my

Received Date: $12^{\text {th }}$ November 2015

Accepted Date: $4^{\text {th }}$ April 2016 